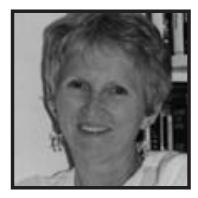

\title{
With Middle Schoolers Slogging in a Cypress Slough
}

\section{Anne McCrary Sullivan, National-Louis University}

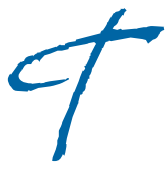

hey line up in columns, face a dark water, know that it's cold.

"Your chaperone will lead your group."

I have no chaperone. I slog free. I wish I had a net.

Philosophically they wade in. "We'll get used to it."'Yeah, we'll get used to it." Soon among cypress trunks, ferns, air plants, their orange vests bloom.

I'm blooming, too - cold water wicking up my jeans.

An orchid there. But they are looking for bladderwort.

"It's got to have clumps below it. Here it is! Nah."

They reach into tangles of floating vegetation, dip with their nets,

peer over buckets."I got something huge, it's two inches long, look, there's two of them! Omigosh, one is eating the other! Or maybe they're mating, I don't know."

Stepping like a water bird, I use a stick to feel my way through submerged roots, cypress knees, logs. A stork feather floats among small rainbows, oil of plant cells bursting.

When Ranger Heather calls us to a soggy congregation, light floats and puddles at our shins. Our feet, our legs have all forgotten the water is cold. We circle and bow

to the mayfly nymph, then release her to her home and slog our way out through marl and tea, single file like nuns or monks, probing ahead of us with sticks, chanting. 


\section{In the Third Grade Museum of Ancient Civilizations}

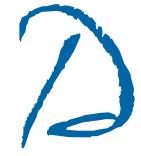

o Not Touch. This vase shows olives

which the Greeks used two ways... to eat

and for hair, to make it shiny. That's why

I made this vase, because of the olives.

For this ancient mask, I used clay, beads, cotton balls, marbles, and a pipe cleaner.

So, you see how I made my artifacts.

This is the Temple of the Acropolis.

This is my name in Greek.

Welcome to China. This is the Great Wall

built to keep their enemies out,

built by Emperor Qui Shi Huangdi-

notice, it's pronounced Chee-Sherr-Hwan-gdi-

and this is the cart where the emperor hid

to keep from dying.

In ancient India, in the Indus River valley, docent Kai displays the blue mud hut he made of clay, its ladder to the roof, the trap door entrance. And this is just a little pot.

This is a game, kind of like checkers.

These are the Himalayas with snowy peaks.

In Rome I learn that Rich Romans wore clothes with color.

The poor wore white, all they could afford. Near the Tiber River, stands poor Roman Barbie draped

in white cotton fabric, loose threads. I get confused, I'm thinking Tigris. I ask, "Where's the Euphrates?"

Nathan cocks his head, looks at me oddly (how can an adult be asking such a thing?), "It's in Mesopotamia." 
Sure enough, there they are, the Tigris and the Euphrates, blue paper flowing down the long table of Mesopotamia and in the famous land between the rivers, five cities: Ur, Erindu, Uruk, Assur, Harran, and Babylon, a ziggurat at the center of every one. My docent loves the ziggurats ... 4 rooms each, and at the top they pray or give food to the gods.

The sand you see is for the desert in Egypt. As you know, the pyramids are found here. This is our pyramid. And here's our mummyKing Tut, the most famous one of all. But my guides can't remember: is it crocodiles or alligators in the Nile? I tell them from my grown-up knowledge (trying to make up for the Tigris) that beyond North America, alligators live only in China. Nathan, arriving from Mesopotamia, says, "Yes, in the Yangtze River."

As my tour ends, a new group of visitors arrives. I stay, observe their travels, their leanings over the Great Wall, the Himalayas, pyramids and ziggurats. When the lights blink, it's time to move, and visitors are led across continents and borders, civilization to civilization, docents of the ancient pointing and explaining.

Now, in hiatus before the next tour, museum personnel sit on the floor. Mrs. Baker reads aloud books made by ninth graders especially for them Scooby Doo in China, Spongebob in India, the Magic Schoolbus in Ancient Greece. 


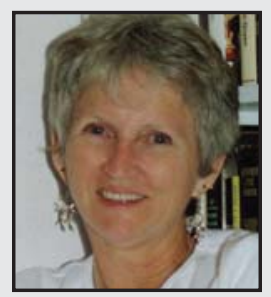

Anne McCrary Sullivan is a poet, naturalist, researcher, and teacher educator with the Florida Regional Campus of National-Louis University. Her poems and her articles relating poetry to teaching and research have appeared in many literary and academic journals including The Gettysburg Review, Southern Review, International Journal of Qualitative Studies in Education, and Harvard Educational Review. Her collection of poems, Ecology II: Poems from The Everglades is in press for January 2009. 